\title{
OPEN Valorization of cigarette butts for synthesis of levulinic acid as top value-added chemicals
}

\begin{abstract}
Amelita G. Laurenza ${ }^{1}$, Onofrio Losito ${ }^{2}$, Michele Casiello ${ }^{2}$, Caterina Fusco ${ }^{3}$, Angelo Nacci ${ }^{2,3}$, Vincenzo Pantone ${ }^{1} \&$ Lucia D'Accolti ${ }^{2,3 凶}$

Unprecedented in the literature, levulinic acid (LA), one of the top value-added intermediates of chemical industry, is obtained from cigarette butts as cellulose feedstock by means of a one-pot hydrothermal process carried out at $200^{\circ} \mathrm{C}$ for $2 \mathrm{~h}$ and catalysed by phosphoric acid. The protocol avoids the use of more aggressive and toxic $\mathrm{H}_{2} \mathrm{SO}_{4}$ and $\mathrm{HCl}$, that are generally employed on several cellulose sources (e.g. sludge paper), thus minimizing corrosion phenomena of plants. Neither chemical pre-treatment of butts nor specific purification procedure of LA are required. Notably, by simply modifying acid catalyst (e.g. using $\mathrm{CH}_{3} \mathrm{COOH}$ ), another top value-added fine chemical such as 5-hydroxymethylfuraldehyde (HMF) is obtained, thus widening the scope of the method. Being cigarette filters a waste available in quantities of megatonnes per year, they represent an unlimited at no cost source of cellulose, thus enabling the up-scale to an industrial level of LA production.
\end{abstract}

The conscious use of the planet's natural resources has become mandatory to ensure the survival of life on earth. To this end, the imperative contribution that the scientific community can provide is to develop new sustainable process and materials, with a significant impact on the social level and with a reduced environmental repercussion. In this context, the tuning of new chemical approaches to exploit the waste has an extreme importance in the realization of the virtuous path that Circular Economy is encouraging, to create environmental and social benefits, in a "Rethinking Progress" approach for sustainable development and sustainability.

Exploiting biomass is the true weapon to face this challenge, the true road for producing energy, fine chemicals and bio-based manufacts in a sustainable manner, thus definitively eliminating the dependence on fossil sources, without loss of soil ${ }^{1}$.

Important examples of biomass are wood and energy crops, such as for example soy, useful for producing biofuels but also bio-based chemicals and polymers ${ }^{2}$. Recent years have witnessed a rapid growth in the production of fuels ${ }^{3}$ and materials entirely deriving from biomasses ${ }^{4}$. However, this has led to many troubles such as improper exploitation of soils (non-food applications), increase of raw materials price (especially in Third World countries), biodiversity reduction, soil erosion and increased risk of insects and bacteria that destroy crops ${ }^{1}$.

Biomass wastes can be the right solution to these problems ${ }^{2}$, constituting a widely available and no cost reservoir of carbohydrates, lipids and proteins, with possible on-site processing, coming from scraps of forests, yards, farms, or municipal waste foods, the proportion of which has been estimated at hundreds of megatonnes (Mt) per year around the world ${ }^{5,6}$.

Carbohydrates, the main component of these vast reservoir, can be converted via biological or chemical routes into Levulinic Acid (LA) $)^{7,8}$, which is considered one of the twelve most promising industrial bio-intermediates and amongst the most innovative building blocks of chemical industry, due to its conversion in several highvalue bio-based chemicals and materials (Fig. 1) ${ }^{7}$. The main end users of LA are agricultural, pharmaceutical, and cosmetic sectors, although this natural molecule also contributes to the creation of new ecological fuels, fertilizers, and pesticides. It is also used in the biodegradable plastics field and as intermediate element for creating high-performance plastic materials, medicines, and many other new concept "green" products, thus allowing to broaden its scope of application. According to the most recent studies, it is estimated that the world market demand for LA will grow 150-200 times over the next 7-8 years ${ }^{8}$.

The well-known approach to convert lignocellulosic materials (wood, paper, food crops wastes) into levulinic acid is the thermal treatment with strong Brønsted acids (e.g. $\mathrm{H}_{2} \mathrm{SO}_{4}$ ) as homogeneous catalysts ${ }^{9,10}$. To date, a twostep continuous process is used to obviate the deterioration of the plants. Hemicellulose and cellulose fractions of

\footnotetext{
${ }^{1}$ Ambra SRL, Via Mitilini 11 Pomarico, 75016 Matera, Italy. ${ }^{2}$ Dipartimento di Chimica, Università degli Studi di Bari "A. Moro", Via Orabona 4, 70126 Bari, Italy. ${ }^{3}$ Bari Section, CNR-Istituto di Chimica dei Composti Organometallici (ICCOM), Via Orabona 4, 70126 Bari, Italy. ${ }^{\circledR}$ email: lucia.daccolti@uniba.it
} 


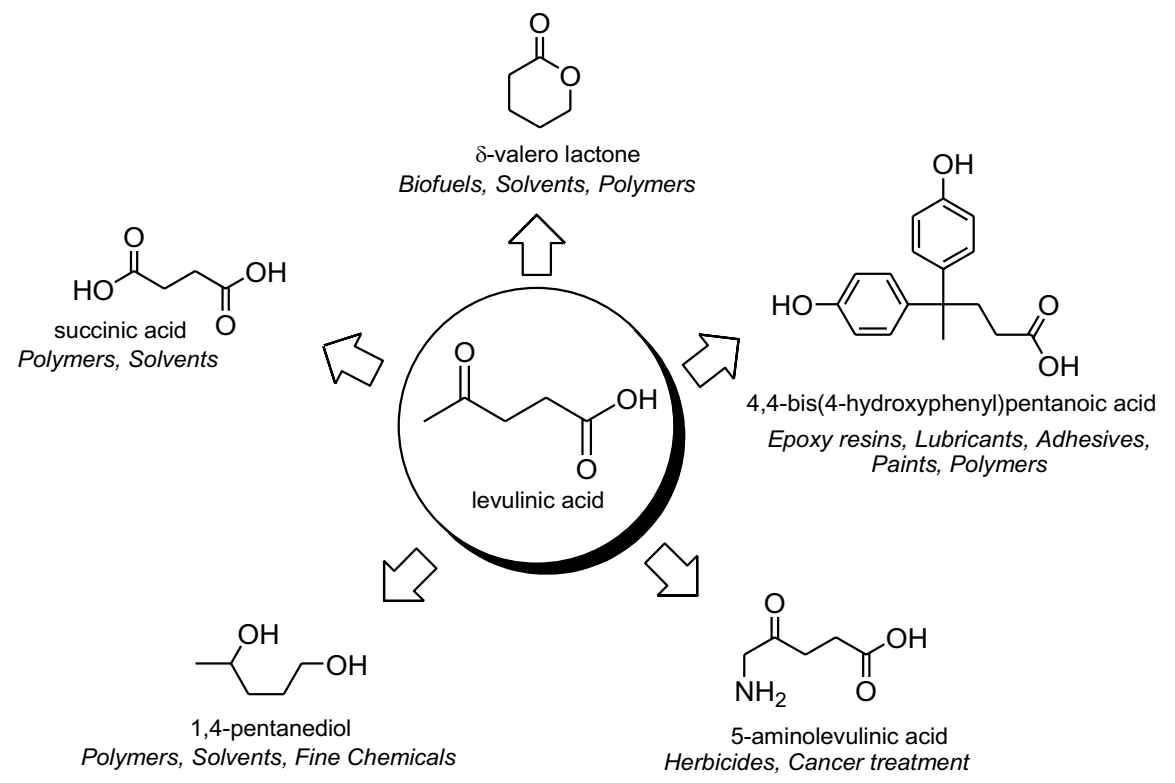

Figure 1. Levulinic acid as a key industrial intermediate.

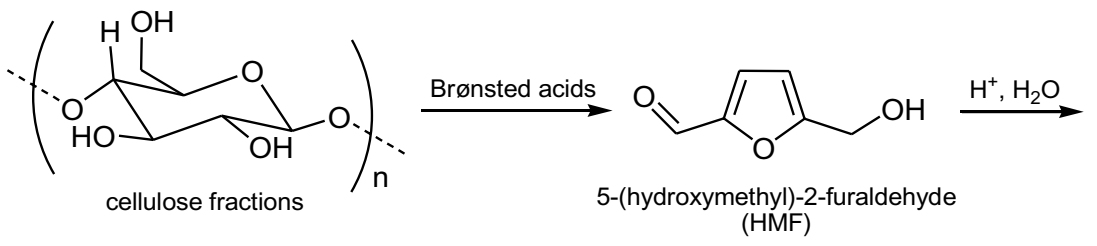<smiles>CC(=O)CCC(=O)O</smiles>

Figure 2. Two-step synthesis of Levulinic Acid.

biomass are preliminarily hydrolyzed in a first reactor (at $210-230{ }^{\circ} \mathrm{C}$, for few seconds in the presence of $1-5 \%$ of mineral acid) producing hydroxymethylfurfural (HMF), that is removed in flow feeding continuously a second reactor where it is further hydrolyzed to produce LA (Fig. 2) ${ }^{10-16}$.

Despite the high yields, this strategy is difficult to apply at an industrial level, due to the harsh conditions and plants corrosion ${ }^{10}$. To date, only few companies can produce LA at commercial scale directly from biomass ${ }^{10,17}$. In recent years, much attention has been paid to producing LA by means of milder and more eco-sustainable conditions ${ }^{16}$, for example employing heterogeneous acid catalysts and green solvents such as water or ionic liquids (ILs) 8,17. $^{8}$.

As regards the cellulosic starting material, beside agricultural scraps ${ }^{10}$, municipal paper wastes are gaining attention ${ }^{17}$. Among these latters, cigarette filters represent a neglected and no cost reservoir of cellulose acetate ${ }^{18}$, that is virtually boundless if considering that about 5.5 trillion cigarettes are produced each year ${ }^{19-21}$. Notably, used cigarette butts (CBs) are considered a dangerous waste, because of the content of organic and heavy metals contaminants, therefore their use as starting raw materials is rather complex and essentially limited to production of asphalts, mesoporous carbon, and cellulose pulp ${ }^{16-22}$. Recently, bioethanol has been produced by fermentation of cellulose obtained by deacetylation of $\mathrm{CBs}^{22}$, but no attempts have been reported until now on their use to produce LA or other fine chemicals.

Following our ongoing interest in developing green protocols obeying to circular economy principles ${ }^{23,24}$ we report herein, unprecedented in the literature, a protocol that exploits cigarettes filters as source of Levulinic acid avoiding the strong acidic conditions and extendable at an industrial level.

\section{Results and discussion}

In the proposed procedure the preliminary digestion with strong acids $\left(\mathrm{H}_{2} \mathrm{SO}_{4}\right)$ was circumvented using a onepot procedure involving $\mathrm{H}_{3} \mathrm{PO}_{4}$. Notably, being composed by cellulose acetate, $\mathrm{CBs}$ fibres must be deacetylated before undergoing deconstruction (swelling of cellulose chains) and hydrolysis. On these bases, phosphoric acid appeared the suitable choice as it is particularly efficient in changing the structure of cellulose by breaking interchain hydrogen bonds favouring deconstruction ${ }^{13}$. In addition, among the widely available mineral acids, $\mathrm{H}_{3} \mathrm{PO}_{4}$ is strong enough to give efficiently deacetylation, deconstruction, and hydrolysis, but is simultaneously low toxic and much less corrosive than $\mathrm{HCl}$ and $\mathrm{H}_{2} \mathrm{SO}_{4}{ }^{25}$, which is also known, the latter, to give partial carbonization of organic substrates. 


\begin{tabular}{|c|c|c|c|c|c|c|}
\hline \multirow[b]{2}{*}{ Entry } & \multirow[b]{2}{*}{ Filters weight $(\mathbf{m g})$} & \multirow[b]{2}{*}{ Catalyst $(M)^{b}$} & \multirow[b]{2}{*}{$\mathrm{T}\left({ }^{\circ} \mathrm{C}\right)$} & \multirow[b]{2}{*}{ Time (h) } & \multicolumn{2}{|c|}{ Levulinic acid yields } \\
\hline & & & & & $(\%)^{c}$ & $(\% \text { filter wt })^{d}$ \\
\hline 1 & 251.24 & - & 200 & 2 & - & - \\
\hline 2 & 253.38 & $\mathrm{H}_{3} \mathrm{PO}_{4}(1.5)$ & 160 & 2 & - & - \\
\hline 3 & 250.38 & $\mathrm{H}_{3} \mathrm{PO}_{4}(1.5)$ & 180 & 2 & 22.5 & 10.43 \\
\hline 4 & 252.85 & $\mathrm{H}_{3} \mathrm{PO}_{4}(1.5)$ & 190 & 2 & 24.7 & 11.42 \\
\hline 5 & 253.19 & $\mathrm{H}_{3} \mathrm{PO}_{4}(1.5)$ & 200 & 2 & 36.7 & $17.32^{\mathrm{e}}$ \\
\hline 6 & 250.57 & $\mathrm{H}_{3} \mathrm{PO}_{4}(1.5)$ & 240 & 2 & 43.9 & $20.28^{\mathrm{e}}$ \\
\hline 7 & 252.93 & $\mathrm{H}_{3} \mathrm{PO}_{4}(1.5)$ & 260 & 2 & 35.4 & $16.36^{\mathrm{f}}$ \\
\hline 8 & 101.70 & $\mathrm{H}_{3} \mathrm{PO}_{4}(1.5)$ & 200 & 2 & 24.3 & 11.28 \\
\hline 9 & 200.80 & $\mathrm{H}_{3} \mathrm{PO}_{4}(1.5)$ & 200 & 2 & 35.7 & 16.47 \\
\hline 10 & 299.50 & $\mathrm{H}_{3} \mathrm{PO}_{4}(1.5)$ & 200 & 2 & 30.1 & 13.90 \\
\hline 11 & 251.55 & $\mathrm{H}_{3} \mathrm{PO}_{4}(0.7)$ & 200 & 2 & 25.2 & 11.46 \\
\hline 12 & 250.96 & $\mathrm{H}_{3} \mathrm{PO}_{4}(\mathbf{2 . 0})$ & 200 & 2 & 41.4 & 19.15 \\
\hline 13 & 250.37 & $\mathrm{H}_{3} \mathrm{PO}_{4}(1.5)$ & 200 & 1 & 17.3 & 8.00 \\
\hline 14 & 251.04 & $\mathrm{H}_{3} \mathrm{PO}_{4}(\mathbf{1 . 5})$ & 200 & 6 & 49.6 & 22.94 \\
\hline 15 & 252.52 & $\mathrm{CH}_{3} \mathrm{COOH}(4)$ & 200 & 2 & - & $-\mathrm{g}$ \\
\hline 16 & 254.06 & $\mathrm{H}_{2} \mathrm{SO}_{4}$ & 200 & 2 & 63.1 & 31.6 \\
\hline
\end{tabular}

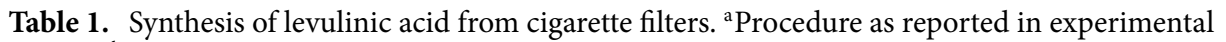
section. ${ }^{b}$ Volume $=15 \mathrm{~mL} .{ }^{~ c}$ Referred to theoretical amount of LA (see "Materials and methods" section). ${ }^{\mathrm{d}}$ Referred to the filter weight ${ }^{14}$. All yield values were obtained based on three replicate experiments $(\mathrm{SD} \pm 2.0)$. ${ }^{\mathrm{e}}$ Humines $=79 \mathrm{mg}(32 \% \mathrm{w} / \mathrm{w})$. Humines $=173 \mathrm{mg}(69 \% \mathrm{w} / \mathrm{w}) .{ }^{\mathrm{f}}$ Humines $=205 \mathrm{mg}(82 \% \mathrm{w} / \mathrm{w})$. g5-hydroxymethylfuraldehyde (HMF) was the main product (see MS spectrum in Supplemental Information).

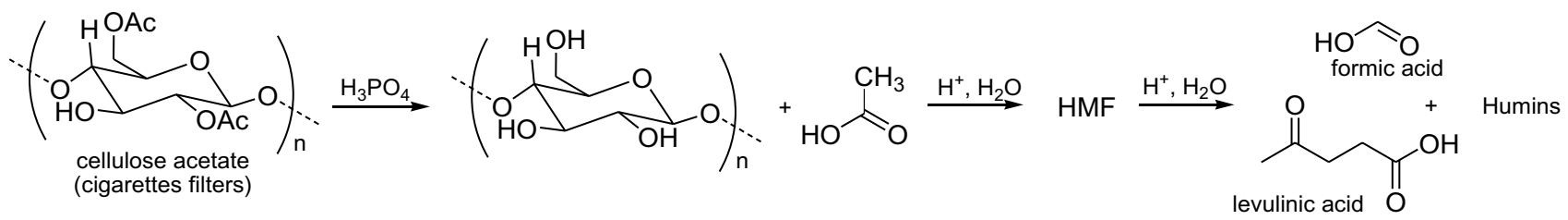

Figure 3. One-step synthesis of Levulinic Acid.

Preliminarily, fresh and used filters were subjected to characterization by LCSM technique for determining fibres morphology, and by ICP/MS and COD analyses for evaluating amounts of contaminants (see supplemental information). According to most of reported procedures, catalytic hydrolysis experiments were conducted in a batch reactor processing $250 \mathrm{mg}$ of filters in $15 \mathrm{~mL}$ of aqueous $\mathrm{H}_{3} \mathrm{PO}_{4}$ at different times and temperatures ${ }^{14}$ (Table 1). Formation of Levulinic Acid was surveyed by GC/MS and NMR techniques. Both unsmoked and smoked cigarette butts were tested as source of cellulose biomass, whereas acetic and formic acids were formed as by-products together with HMF as an intermediate (Fig. 3) ${ }^{16,26}$.

Blank reaction carried out in the absence of $\mathrm{H}_{3} \mathrm{PO}_{4}$ led to the complete recovery of unreacted filters, thus confirming that Brønsted acids are true catalysts for the process (Table 1, entry 1 ). The successive experiments, aimed at evaluating the temperature effect, showed that reaction requires a minimum heating at $180{ }^{\circ} \mathrm{C}$, displaying the maximum yield of $43.9 \%$ in levulinic acid at $240{ }^{\circ} \mathrm{C}$ (Table 1, entries 2-6). However, the increase of temperature led also to significant increments of humins by-products (Table 1, entries 5-7).

Amount of starting material proved to be a further parameter affecting reaction yield, with $250 \mathrm{mg}$ representing the optimal value (Table 1 , entries 5, 8-10). Catalyst loading and reaction time were also investigated. In the former case, the increment of concentration of aqueous $\mathrm{H}_{3} \mathrm{PO}_{4}$ up to $2.0 \mathrm{M}$ resulted in a neglectable increase of yield in levulinic acid respect to preliminary experiments, thus suggesting that $1.5 \mathrm{M}$ is the best value (Table 1, entries 5, 11-12). In contrast, much prolonged times afforded beneficial effects on reaction yields, allowing to reach a $49.6 \%$ of yield in levulinic acid after $6 \mathrm{~h}$ (Table 1, entries 13-14). As expected, no conversion in LA was observed when $\mathrm{H}_{3} \mathrm{PO}_{4}$ was replaced by a weak acid such as $\mathrm{CH}_{3} \mathrm{COOH}$. Notably, in this case another value-added fine chemical, namely 5-hydroxymethylfuraldehyde (HMF), was observed as unique product, widening the scope of this method (Table 1, entry 15). Finally, reaction with sulfuric acid (entry 16 Table 1 ) gave $32 \%$ of yield, this result confirms that sulphuric acid can catalyse the one-pot conversion into LA with good efficiency, but the concentration of $1.5 \mathrm{M}$ requested is prohibitive for an extension at industrial level, due to corrosion problems, and the two-stage strategy is a mandatory choice.

Attempts were done to increase the yields of levulinic acid, re-submitting residual humins by-products to the hydrolysis conditions at higher temperatures and prolonged reaction times. The total absence of products 


\begin{tabular}{|c|c|c|c|c|c|c|c|}
\hline \multirow[b]{2}{*}{ entry } & \multirow[b]{2}{*}{ Raw material (weight) } & \multirow[b]{2}{*}{ Catalyst $(M)^{a}$} & \multirow[b]{2}{*}{$\mathrm{T}\left({ }^{\circ} \mathrm{C}\right)$} & \multirow[b]{2}{*}{ Time (h) } & \multicolumn{2}{|c|}{ LA yields } & \multirow[b]{2}{*}{ Ref } \\
\hline & & & & & $(\%)^{\mathbf{b}}$ & $(\% \text { filter wt })^{c}$ & \\
\hline 1 & Washed filter $(251.15 \mathrm{mg})$ & $\mathrm{H}_{3} \mathrm{PO}_{4}(\mathbf{1 . 5 )}$ & 200 & 2 & 33 & 15.30 & This work \\
\hline 2 & Unwashed filter $(251.29 \mathrm{mg})$ & $\mathrm{H}_{3} \mathrm{PO}_{4}(\mathbf{1 . 5 )}$ & 200 & 2 & 31 & 14.31 & This work \\
\hline 3 & Filter-paper cellulose $^{\mathrm{d}}$ & $\mathrm{H}_{3} \mathrm{PO}_{4}(0.15)$ & 200 & 2 & - & 40 & 13 \\
\hline 4 & Paper sludge & $\mathrm{H}_{2} \mathrm{SO}_{4}(0.47)$ & 200 & 1 & 26.5 & 15.1 & 14 \\
\hline 5 & Paper sludge & $\mathrm{HCl}(0.47)$ & 200 & 1 & 55.1 & 31.4 & 14 \\
\hline
\end{tabular}

Table 2. Synthesis of levulinic acid from smoked cigarette filters. Procedure as reported in experimental section. ${ }^{a}$ Volume $=15 \mathrm{~mL} .{ }^{\text {b }}$ Referred to theoretical amount of LA (see "Materials and methods" section). ${ }^{\mathrm{c}}$ Referred to the filter weight ${ }^{14}$. All yield values were obtained based on three replicate experiments $(\mathrm{SD} \pm 2.0)$. ${ }^{\mathrm{d}}$ The pretreatment temperature and time were set to $50^{\circ} \mathrm{C}$ and $24 \mathrm{~h}$.

indicated that such conditions are not strong enough to give the cleavage of the furan-based polymeric skeleton of humins (Eq. 1).<smiles>CC(C)(C)OCc1ccc(C(OCc2ccc(C=O)o2)OCc2ccc(C(=O)C(Cc3ccc(C(=O)O)o3)c3ccc(C(=O)Cc4ccc(C(C)(C)C)o4)o3)o2)o1</smiles>

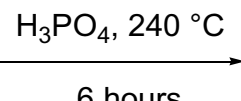

N. R.

Results in Table 1 showed that the best hydrolysis conditions are $240^{\circ} \mathrm{C}$ for $2 \mathrm{~h}$ or $200{ }^{\circ} \mathrm{C}$ for $6 \mathrm{~h}$ (Table 1 , entries 6 and 14). Nevertheless, in both these cases, greater quantities of solid residue were observed probably due to the higher temperature and the longer times. Therefore, milder conditions of $200^{\circ} \mathrm{C}$ for $2 \mathrm{~h}$ were selected for the successive experiments aimed at studying both real waste samples such as the smoked filters and the influence of their pre-treatment (e.g. washing).

At this end, smoked cigarette filters were washed with $100 \mathrm{ml}$ of water at $80^{\circ} \mathrm{C}$ for three times. The collected water fractions were extracted with ethyl acetate and the organic phase was analysed by GC/MS revealing triacetin (triacetylglycerin) as the main product, which is a humectant additive, and trace amounts of phenolic compounds.

As reported in Table 2 (entries 1-2), almost identical results in terms of yields were obtained with washed and unwashed cigarette butts.

Data in Table 2 (entries 4-5) also show that this protocol can favourably compete with analogous ones reported in the literature based on the use of $\mathrm{H}_{2} \mathrm{SO}_{4}$ and $\mathrm{HCl}$, in that very similar yields of levulinic acid can be obtained with a less corrosive acid and low toxic $\mathrm{H}_{3} \mathrm{PO}_{4}$ thus minimizing the corrosion phenomena ${ }^{12,13,25}$.

In addition, we have also avoided the thermal pre-treatment, which although it increases the yield of levulinic acid, requires a greater expenditure of energy. (entries 3).

Moreover, NMR analyses (Fig. 4) of crude reaction product of unwashed cigarette butts, revealed that levulinic acid was obtained with the same high degree of purity of that obtained with unsmoked filters (besides a little solvent residue removable in vacuo).

These results suggest that that dirt or contaminants of the smoked cigarettes do not interfere with the reaction outcome ${ }^{20,21}$ and that the method is highly selective and does not require neither special pre-treatment of the starting waste material nor specific purification procedure of the reaction product.

Further aspects that represent crucial advantages for a plausible industrial application of this method concern: (i) the possibility of recycling humins wastes through thermal valorisation (burning) or syn-gas production ${ }^{27}$, although more recently they have been used for producing macroporous foam-like materials ${ }^{28}$; (ii) the prompt recycle (by distillation) of Ethyl Acetate used for extracting Levulinic acid; (iii) the possibility of recovering water phase by eliminating phosphoric acid and metal through precipitation ${ }^{29,30}$ and COD by Fenton treatments ${ }^{31}$.

These latter are two typical and cheap treatments of industrial wastewater, after which the liquid can be poured into rivers and is still considered surface water. Phosphate anions and metals are precipitated with calcium hydroxide in the form of hydroxyapatite, which is disposed of after flocculation as sludge. At the same time, most of metal contaminants are precipitated as oxides. Then, water is subjected to Fenton process (with $\mathrm{H}_{2} \mathrm{O}_{2} / \mathrm{Fe}$ salts) for the oxidation of the organic residues allowing the achievement of the legal limits of COD $<160 \mathrm{mg} / \mathrm{L}$.

A complete process diagram of this protocol is listed in Fig. 5. In line with Green Chemistry and Circular Economy principles, an E-factor of 19.08 (about 9 with $\mathrm{H}_{3} \mathrm{PO}_{4}$, but with heat pre-treatment ${ }^{13}$ ), very close to 
a)<smiles>CC(=O)CCC(=O)O</smiles>

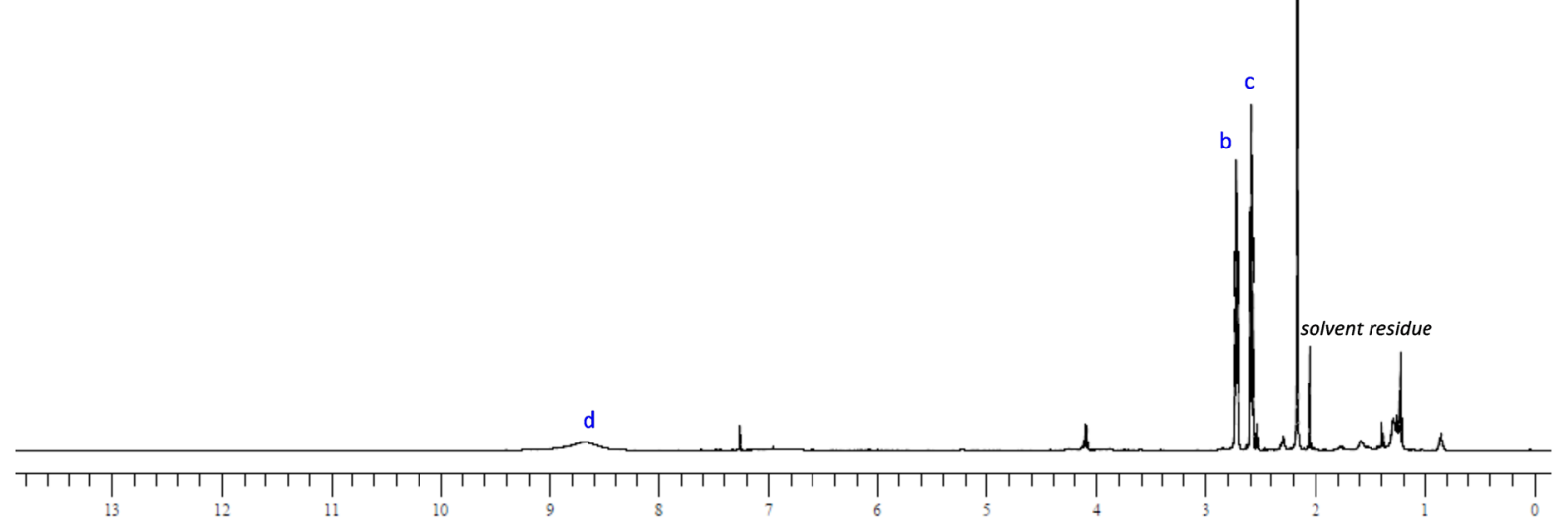

b)

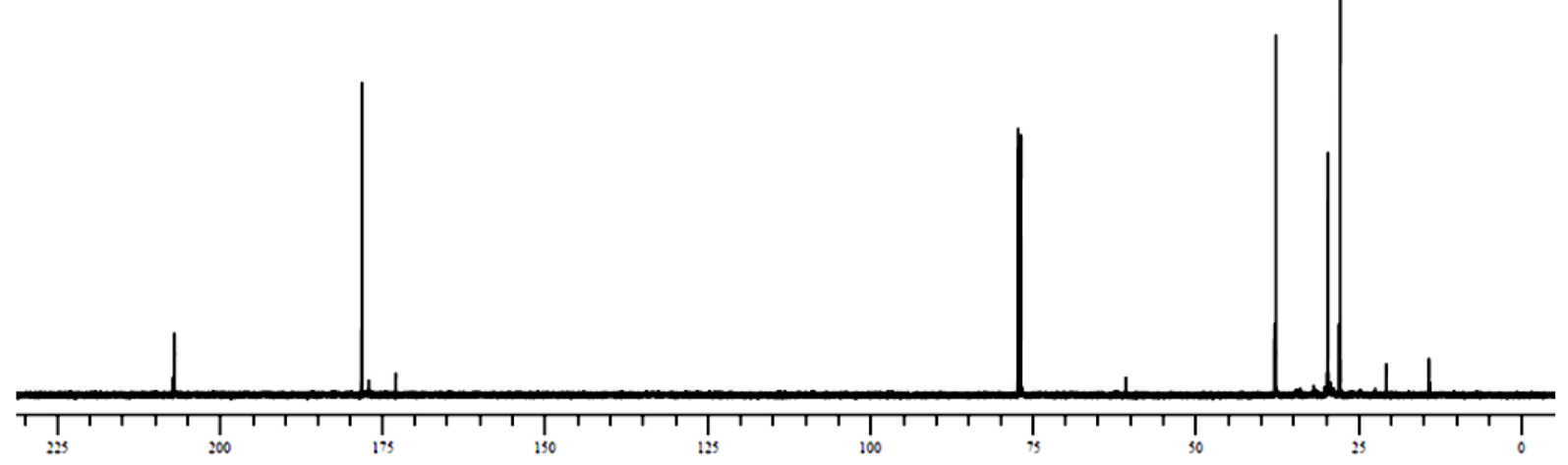

Figure 4. (a) ${ }^{1} \mathrm{H}-\mathrm{NMR}$ and (b) ${ }^{13} \mathrm{C}-\mathrm{NMR}$ spectra $\left(\mathrm{CDCl}_{3}\right)$ of crude product from smoked unwashed filter.

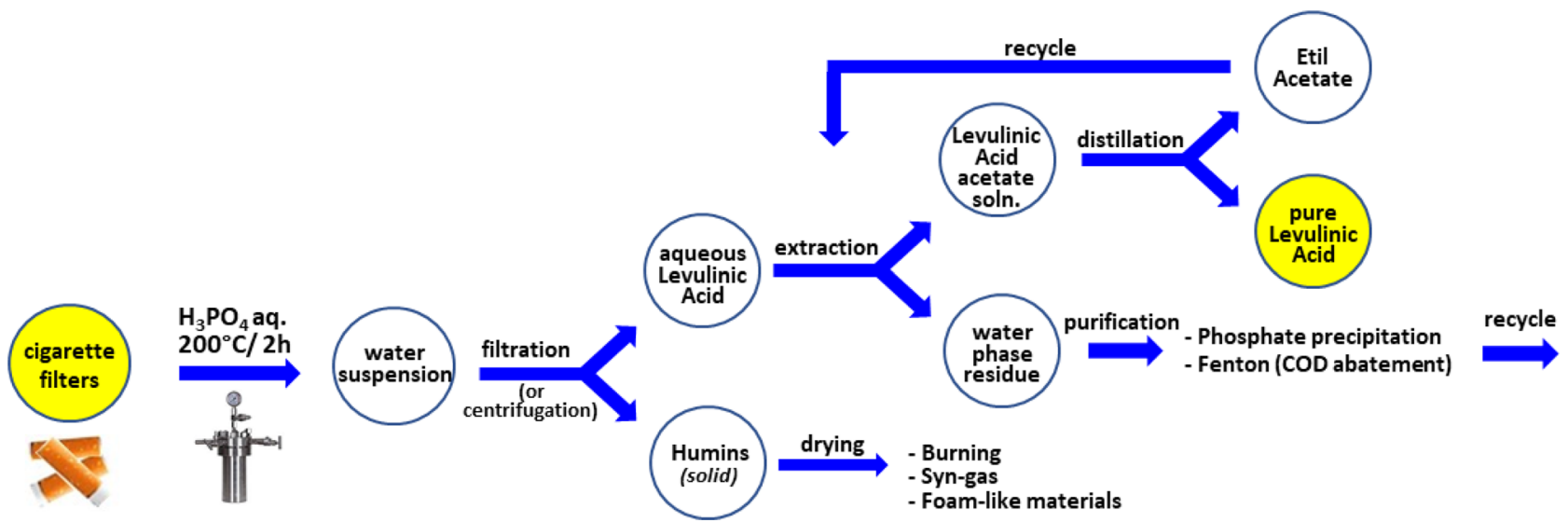

Figure 5. Process diagram of proposed method. 
that of the pharmaceutical industries and chemical industry ${ }^{32}$, was calculated taking into account that most of material involved can be recycled and valorized such as in the case of humins that represent a new platform for production of mesoporous carbons.

\section{Conclusion}

Unprecedented in the literature, cigarette butts can be used as cellulose feedstock for producing Levulinic acid, one of the top value-added intermediates of chemical industry, by means of thermal hydrolysis (at $200{ }^{\circ} \mathrm{C}$ for $2 \mathrm{~h}$ ) catalysed by phosphoric acid. The proposed protocol avoids the use of more aggressive $\mathrm{H}_{2} \mathrm{SO}_{4}$ and $\mathrm{HCl}$, that are generally used for promoting this transformation from other cellulose sources (e.g. sludge paper), thus minimizing corrosion phenomena of plants. Further benefits that enable this method to be suitable for industrial applications are the following:

- reaction does not require neither pre-treatment of the starting material nor specific purification procedure of levulinic acid product;

- the possibility of recycling all the process components, ranging from humins by-products (by thermal valorisation), to the extracting solvent Ethyl acetate (by distillation), until to water phase residue (by Fenton COD abatement);

- the opportunity of obtaining, by simply modifying acid catalyst (e.g. using $\mathrm{CH}_{3} \mathrm{COOH}$ ), another top valueadded fine chemical such as 5-hydroxymethylfuraldehyde (HMF), thus widening the scope of the protocol.

Further advantages such as the huge amount of cigarette filters (megatonnes per years) that provide a no cost unlimited source of cellulose, suggest that this protocol marks a significant step forward compared to the current literature on this important issue.

\section{Materials and methods}

Materials. Ethyl acetate (>99\%) was purchased by Honeywell, Phosphoric acid (85\%) and Levulinic acid were purchased from Sigma-Aldrich. All the reagents and solvents were used as received, without any further treatment. GC-MS analyses were run on a Shimadzu GLC 17-A instrument (Shimadzu, MI, Italy) using a SLB$5 \mathrm{MS}$ column $(30 \mathrm{~m} \times 0.25 \mathrm{~mm}$ id, film thickness $0.25 \mu \mathrm{m})$. Mass spectra were performed in EI mode $(70 \mathrm{eV})$ and yields of LA were determined via GC-MS by means of a calibration curve (see supplemental information). NMR spectra were recorded on a Bruker $500 \mathrm{MHz}$ spectrometer: ${ }^{1} \mathrm{H}$ NMR $(500 \mathrm{MHz})$ spectra were referenced to residual isotopic impurity of $\mathrm{CDCl}_{3}(7.25 \mathrm{ppm})$ and ${ }^{13} \mathrm{C}-\mathrm{NMr}(125 \mathrm{MHz})$ spectra were referenced to $77.00 \mathrm{ppm}$. Laser confocal scanning microscopy analyses were performed with an LSM-510 confocal microscope (Zeiss). ICP/MS analyses were carried out with a Thermo Fisher iCAP RQ (ICP-MS) instrument. COD analyses were performed with QuickCOD Labservice instrument. ATR-FTIR spectra were carried out on a Perkin-Elmer UATR-Two spectrophotometer instrument equipped with a single reflection diamond ATR crystal (refractive index of 2.4). Spectra were acquired with 32 scans in the range $4000-600 \mathrm{~cm}^{-1}$ by applying both the baseline and the ATR corrections.

Levulinic acid synthesis. Weighed amounts of cigarette butts (250 mg ca. of "Rizla + ultra slim $5.7 \mathrm{~mm}$ ") were finely chopped in small pieces and suspended into $15 \mathrm{~mL}$ of aqueous $\mathrm{H}_{3} \mathrm{PO}_{4}$. Three different concentrations of $\mathrm{H}_{3} \mathrm{PO}_{4}$ were explored: $7.5 \% \mathrm{w} / \mathrm{w}, 15 \% \mathrm{w} / \mathrm{w}$, and $20 \% \mathrm{w} / \mathrm{w}$. Each suspension was charged into a $100 \mathrm{~mL}$ stainless steel autoclave and heated at temperatures in the range $160-260{ }^{\circ} \mathrm{C}$ for different times $(1-6 \mathrm{~h})$. After cooling, mixture was filtered and/or centrifugated to separate solid "Humins", that were dried and weighed to give from 20 to $80 \%$ of yield (depending on the reaction conditions), while supernatant was extracted with ethyl acetate $(2 \times 20 \mathrm{~mL})$. Combined organic phases were dried and the solvent removed in vacuo to give levulinic acid as crude oil.

Optimized procedure was then applied to washed and non-washed smoked cigarette butts recovered in Chemistry Department of Bari University, that were previously disinfected under UV rays and mechanically separated by the surrounding paper. A test was also carried out using unsmoked filter and $15 \mathrm{~mL}$ of aqueous $\mathrm{CH}_{3} \mathrm{COOH}$ $4 \mathrm{M}$ in place of $\mathrm{H}_{3} \mathrm{PO}_{4}$ as catalyst. Used cigarette butts were washed in three cycles with $100 \mathrm{~mL}$ of water at $80{ }^{\circ} \mathrm{C}$.

Synthesis of levulinic acid on grams scale. To validate the protocol, reaction was repeated on grams scale. At this end, $5 \mathrm{~g}$ of unwashed smoked filter were treated, in autoclave, with $300 \mathrm{~mL}$ of aqueous $\mathrm{H}_{3} \mathrm{PO}_{4} 15 \%$ (w:w) for $2 \mathrm{~h}$. Mixture was filtered and aqueous solution transferred into a separating funnel and extracted with Ethyl Acetate. The combined organic phases were distillated in vacuum to give $0.85 \mathrm{gr}$ of Levulinic acid, while humins fraction was $1.4 \mathrm{~g}$ (corresponding to $28 \% \mathrm{w} / \mathrm{w}$ respect to the starting waste material).

Humins were characterized by ATR-FT /IR ${ }^{28}$ (see Supplemental Information), while Levulinic acid by ${ }^{1} \mathrm{H}$ $\mathrm{NMR}$ and ${ }^{13} \mathrm{C}-\mathrm{NMR}$ and GC/MS. All the spectra agreed with literature ${ }^{33}$. Levulinic acid (LA): colorless liquid, bp 106-110 ${ }^{\circ} \mathrm{C} / 6 \mathrm{mmHg} ;{ }^{1} \mathrm{HNMR}\left(\mathrm{CDCl}_{3}, 500 \mathrm{MHz}\right): 2.72(\mathrm{t}, \mathrm{J}=6.5 \mathrm{~Hz}, 2 \mathrm{H}), 2.58$ (t, J =6.5 Hz, $\left.2 \mathrm{H}\right), 2.16$ (s, $3 \mathrm{H}) ;{ }^{13} \mathrm{CNMR}(\mathrm{CDCl} 3,125 \mathrm{MHz}): 206.6,178.2,37.7,29.7,27.8$, GC/MS (70 eV) m/z (rel. intensity): 116.00 $(\mathrm{M}+, 2.74), 56.00(28.82) 43.00(100)$.

Calculations and data analysis. Two different yields in Levulinic acid were calculated based on weight of filters and on theoretical amounts of LA. The first one, was calculated with the ratio Levulinic acid (g) obtained after the reaction/cigarette butts $(\mathrm{g}) \times 100^{14}$. 
The theoretical maximum yield ${ }^{13,14}$ of Levulinic acid is calculated on $250 \mathrm{mg}$ of cigarette butts that contain $245 \mathrm{mg}(98 \% \mathrm{ca} \text {.) of cellulose acetate (C.A.) })^{19}$. Considering a 2:1 stoichiometric ratio of transformation (a dimeric C.A. unit leads to 2 molecules of Levulinic acid) and that C.A. dimeric unit molecular weight (MW $\left.\mathrm{M}_{\text {C.A. }}\right)$ is $492.428 \mathrm{mg} / \mathrm{mmol}$, the C.A. millimoles can be calculated as follows:

$$
\operatorname{mmol}_{\text {C.A }}=\operatorname{mg}_{\text {C.A. }} / \mathrm{MW}_{\text {C.A. }}=[245 \mathrm{mg} / 492.428 \mathrm{mg} / \mathrm{mmol}]=0.4975 \mathrm{mmol} \text {. }
$$

Cellulose acetate total conversion leads to $2 \mathrm{~mol}$ of L.A. $\left(P_{\cdot M_{\text {L.A }}}=116.11 \mathrm{mg} / \mathrm{mmol}\right)$ per cellulose acetate dimeric unit.

L.A. maximum millimoles and milligrams are obtained as follows:

$$
\begin{aligned}
& \mathrm{mmol}_{\text {L.A. }}=\mathrm{mmol}_{\text {C.A. }} \times 2=0.995 \mathrm{mmol} . \\
& \mathrm{mg}_{\text {L.A. }}=\mathrm{mm}_{\text {L.A. }} \times \mathrm{PM}_{\text {L.A. }}=[0.995 \mathrm{mmol} \times 116.11 \mathrm{mg} / \mathrm{mmol}]=115.54 \mathrm{mg} .
\end{aligned}
$$

Theoretical maximum yield (\% W/W) can be calculated as follows:

$$
\operatorname{Rmax}(\%)=(\operatorname{mgL} . \text { A. } / 250 \mathrm{mg}) \times 100=(115.54 \mathrm{mg} / 250 \mathrm{mg}) \times 100]=46.2 \%
$$

Theoretical yield was calculated as $\mathrm{mm}_{\text {L.Aex }} / \mathrm{mm}_{\text {L.Ath }} \times 100$.

The $\mathrm{mm}_{\mathrm{L} . \mathrm{Aex}}$ was obtained using the GC calibration curve in Supplemental Information.

Determination of E-factor ${ }^{4}$. Mass of reactants: $2.2 \mathrm{~g}$ of $\mathrm{H}_{3} \mathrm{PO}_{4}(85 \%)$ in $15 \mathrm{~mL}$ of water (solvent (water) has been excluded from this calculation), cigarette filter $0.250 \mathrm{~g}$; total amount of reactants $2.2 \mathrm{~g}+0.250 \mathrm{~g}=2.45 \mathrm{~g}$.

$$
\begin{aligned}
& \text { Mass of product }: 0.043 \mathrm{~g} \text { of } \mathrm{LA}+0.079 \mathrm{~g} \text { Humins }=0.122 . \\
& \text { Amount of waste }:(2.45-0.122)=2.38 \text {. } \\
& \mathrm{E} \text { - factor }=\text { Amount of waste/Amount of product }=2.38 / 0.122=19.08 \text {. }
\end{aligned}
$$

Received: 4 March 2021; Accepted: 26 July 2021

Published online: 04 August 2021

\section{References}

1. Pérez, A. P. \& Eugenio, N. R. Status of local soil contamination in Europe: Revision of the indicator "Progress in the management contaminated sites in Europe, EUR 29124 EN". Publ. Off. Eur. Union Luxembourg https://doi.org/10.2760/0938041 (2018).

2. Mennino, S. Valorization of waste: Sustainable organocatalysts from renewable resources. Chemsuschem 13, 439-468 (2020).

3. Massaro, M. et al. One-pot synthesis of $\mathrm{ZnO}$ nanoparticles supported on halloysite nanotubes for catalytic applications. Appl. Clay Sci. 189, 105527. https://doi.org/10.1016/j.clay.2020.105527 (2020).

4. Pantone, V. et al. One-pot conversion of epoxidized soybean oil (ESO) into soy-based polyurethanes by $\mathrm{MoCl} 2 \mathrm{O} 2 \mathrm{catalysis}$. Molecules 22, 333. https://doi.org/10.3390/molecules220203332017 (2017).

5. Tuck, C. O., Pérez, E., Horváth, I. T., Sheldon, R. A. \& Poliakoff, M. Valorization of biomass: Deriving more value from waste. Science 337, 695-699. https://doi.org/10.1126/science.1218930 (2012).

6. Chen, S. S., Maneerung, T., Tsang, D. C. W., Ok, S. Y. \& Wang, C.-H. Valorization of biomass to hydroxymethylfurfural, levulinic acid, and fatty acid methyl ester by heterogeneous catalysts. Chem. Eng. J. 328, 246-273. https://doi.org/10.1016/j.cej.2017.07.020 (2017).

7. Werpy, T. \& Petersen, G. Top Value Added Chemicals from Biomass: Results of Screening for Potential Candidates from Sugars and Synthesis Gas. 1-76 (Department of Energy, 2004).

8. Badgujara, K. C., Wilson, L. D. \& Bhanagea, B. M. Recent advances for sustainable production of levulinic acid in ionic liquids from biomass: Current scenario, opportunities and challenges. Renew. Sustain. Energy Rev. 102, 266-284. https://doi.org/10.1016/j. rser.2018.12.007 (2019).

9. Signoretto, M., Taghavi, S., Ghedini, E. \& Menegazzo, F. Catalytic production of levulinic acid (LA) from actual biomass. Molecules 24, 2760. https://doi.org/10.3390/molecules24152760 (2019).

10. Pileidis, F. D. \& Titirici, M. M. Levulinic acid biorefineries: New challenges for efficient utilization of biomass. Chemsuschem 9 , 562-582. https://doi.org/10.1002/cssc.201501405 (2016).

11. Chen, S. S. et al. Valorization of lignocellulosic fibres of paper waste into levulinic acid using solid and aqueous Brønsted acid. Bioresour. Technol. 247, 387-394. https://doi.org/10.1016/j.biortech.2017.09.110 (2018).

12. Fitzpatrick, S. W. Production of levulinic acid from carbohydrate-containing materials. in US Patent US005608105A (1997).

13. Muranaka, Y., Suzuki, T., Sawanishi, H., Hasegawa, I. \& Mae, K. Effective production of levulinic acid from biomass through pretreatment using phosphoric acid, hydrochloric acid, or ionic liquid. Ind. Eng. Chem. Res. 53, 11611-11621. https://doi.org/10. 1021/ie501811x.| (2014).

14. Raspolli, G. A., Antonetti, C., De Luise, V., Licursi, D. \& Di Nasso, N. N. O. Levulinic acid from waste biomasses. BioResources 7(2), 1824-1834 (2012).

15. Kumar, V. B., Pulidindi, I. N., Mishra, R. K. \& Gedanken, A. Development of Ga salt of molybdophosphoric acid for biomass conversion to levulinic acid. Energy Fuels 30, 10583-10591. https://doi.org/10.1021/acs.energyfuels.6b02403 (2016).

16. Raspolli, G. A., Antonetti, C., Fulignati, S. \& Licursi, D. Direct alcoholysis of carbohydrate precursors and real cellulosic biomasses to alkyl levulinates: A critical review. Catalysts 10(10), 1221. https://doi.org/10.3390/catal10101221 (2020).

17. Dutta, S. Influence of green solvent on levulinic acid production from lignocellulosic paper waste. Bioresour. Technol. $298,122544$. https://doi.org/10.1016/j.biortech.2019.122544 (2020).

18. Marinello, S., Lolli, F., Gamberini, R. \& Rimini, B. A second life for cigarette butts? A review of recycling solutions. J. Hazard. Mater 384, 121245. https://doi.org/10.1016/j.jhazmat.2019.121245 (2020).

19. Kurmus, H. \& Mohajerani, A. The toxicity and valorization options of cigarette butts. Waste Manag. 104, 104-118. https://doi.org/ 10.1016/j.wasman.2020.01.011 (2020).

20. Torkashvand, J. \& Farzadkia, M. A systematic review on cigarette butt management as a hazardous waste and prevalent litter: Control and recycling. Environ. Sci. Pollut. Res. Int. 26, 11618-11630. https://doi.org/10.1007/s11356-019-04250-x (2019). 
21. Torkashvand, J., Farzadkia, M., Sobhi, H. R. \& Esrafili, A. Littered cigarette butt as a well-known hazardous waste: A comprehensive systematic review. J. Hazard. Mater 383, 121242. https://doi.org/10.1016/j.jhazmat.2019.121242 (2020).

22. Shen, F. Deacetylation processing of waste cigarette butts for high-titer bioethanol production toward a clean recycling process. ACS Sustain. Chem. Eng. 8, 11253-11262. https://doi.org/10.1021/acssuschemeng.0c03979 (2020).

23. Mastrorilli, P. et al. Ionic liquids in palladium-catalyzed cross-coupling reactions. Top. Organomet. Chem. 51, 237-286. https:// doi.org/10.1007/3418_2013_64 (2015).

24. Annese, C., D’Accolti, L., Fusco, C., Licini, G. \& Zonta, C. Heterolytic (2e) vs homolytic (1e) oxidation reactivity: N-H versus C-H switch in the oxidation of lactams by dioxirans. Chem. Eur. J. 23, 259-262. https://doi.org/10.1002/chem.201604507 (2017).

25. https://www.materials.sandvik/en/materials-center/corrosion-tables/sulphuric-acid; https://www.materials.sandvik/en/mater ials-center/corrosion-tables/phosphoric-acid/; https://www.materials.sandvik/en/materials-center/corrosion-tables/hydrochlor ic-acid (web data 02/28/2021).

26. Girisuta, B., Janssen, L. P. B. M. \& Heeres, H. J. Green chemicals a kinetic study on the conversion of glucose to levulinic acid. Chem. Eng. Res. Des. 84(A5), 339-349. https://doi.org/10.1205/cherd05038 (2006).

27. Hoang, T. M. C. et al. Humin based by-products from biomass processing as a potential carbonaceous source for synthesis gas production. Green Chem. 17, 959. https://doi.org/10.1039/c4gc01324g (2015).

28. Tosi, P. Auto-crosslinked rigid foams derived from biorefinery byproducts. Chemsuschem 11, 2797-2809. https://doi.org/10.1002/ cssc. 201800778 (2018).

29. Bunce, J. T., Ndam, E., Ofiteru, I. D., Moore, A. \& Graham, D. W. A review of phosphorus removal technologies and their applicability to small-scale domestic wastewater treatment systems. Front. Environ. Sci. 6, 1-15. https://doi.org/10.3389/fenvs.2018. 00008 (2018).

30. Chen, B. et al. Heavy metal and phosphorus removal from waters by optimizing use of calcium hydroxide and risk assessment. Environ. Pollut. 1, 38-54. https://doi.org/10.5539/ep.v1n1p38 (2012).

31. Zhang, M.-H., Dong, H., Zhao, L. \& Wang, D.-X. A review on Fenton process for organic wastewater treatment based on optimization perspective. Sci Total Environ. 670, 110-121. https://doi.org/10.1016/j.scitotenv.2019.03.180 (2019).

32. Williams, R. T., \& Williams, T. R. Green Techniques for Organic Synthesis and Medicinal Chemistry. 1st Edn. 33-67 (Eds. Zhang, W., Cue Jr., B.W.) ISBN 978-0-470-71151-4 (Wiley, 2012).

33. Chaudhari, D. A. \& Fernandes, R. A. Hypervalent iodine as a terminal oxidant in Wacker-type oxidation of terminal olefins to methyl ketones. J. Org. Chem. 81, 2113-2121. https://doi.org/10.1021/acs.joc.6b00137 (2016).

\section{Acknowledgements}

This work is partially supported by funds from European Union-19 FESR "PON Ricerca e Innovazione 20142020. Progetto: 20 Energie per l'Ambiente TARANTO-Cod. ARS01_00637”.

\section{Author contributions}

Conceptualization, A.G.L., V.P. and L.D., methodology, M.C., A.G.L., O.L., investigation, O.L.A. G.L., M.C., data curation, C.F., A.N., V.P., L.D. writing-original draft preparation, A.N. and C. F., review and editing. All authors have read and agreed to the published version of the manuscript.

\section{Competing interests}

The authors declare no competing interests.

\section{Additional information}

Supplementary Information The online version contains supplementary material available at https://doi.org/ 10.1038/s41598-021-95361-4.

Correspondence and requests for materials should be addressed to L.D.

Reprints and permissions information is available at www.nature.com/reprints.

Publisher's note Springer Nature remains neutral with regard to jurisdictional claims in published maps and institutional affiliations.

Open Access This article is licensed under a Creative Commons Attribution 4.0 International License, which permits use, sharing, adaptation, distribution and reproduction in any medium or format, as long as you give appropriate credit to the original author(s) and the source, provide a link to the Creative Commons licence, and indicate if changes were made. The images or other third party material in this article are included in the article's Creative Commons licence, unless indicated otherwise in a credit line to the material. If material is not included in the article's Creative Commons licence and your intended use is not permitted by statutory regulation or exceeds the permitted use, you will need to obtain permission directly from the copyright holder. To view a copy of this licence, visit http://creativecommons.org/licenses/by/4.0/.

(C) The Author(s) 2021 